\title{
Ornithodoros quilinensis sp. nov. (Acari, Argasidae), a new tick species from the Chacoan region in Argentina
}

\author{
José M. Venzal ${ }^{1 *}$, Santiago Nava², Atilio J. Mangold², Mariano Mastropaolo², \\ Gustavo Casás ${ }^{3}$ and Alberto A. Guglielmone ${ }^{2}$ \\ ${ }^{1}$ Departamento de Parasitología Veterinaria, Facultad de Veterinaria, Universidad de la República, Regional Norte-Salto, Rivera 1350, \\ CP 50000 Salto, Uruguay; ${ }^{2}$ Instituto Nacional de Tecnología Agropecuaria, Estación Experimental Agropecuaria Rafaela, CC 22, \\ CP 2300 Rafaela, Santa Fe, Argentina; ${ }^{3}$ Departamento de Parasitología Veterinaria, Facultad de Veterinaria, Universidad de la República, \\ Alberto Lasplaces 1620, CP 11600 Montevideo, Uruguay
}

\begin{abstract}
Ornithodoros quilinensis sp. nov. (Acari: Argasidae) is described from larvae collected on the small rodents Graomys centralis (Cricetidae: Sigmodontinae) in Argentina. The diagnostic characters for this new species are a combination of small size (520$540 \mu \mathrm{m}$ ), a dorsal plate oval in shape with a length of approximately $200 \mu \mathrm{m}, 14$ pairs of dorsal setae, hypostome short and narrower at the base (length from $\mathrm{Ph}_{1}$ to apex $133 \mu \mathrm{m}(120-141)$ ) with dental formula $2 / 2$ and apex blunt, and the capsule of the Haller's organ irregular in shape and without reticulations. The analysis of the $16 \mathrm{~S}$ rDNA sequences available for the genus Ornithodoros indicate that, phylogenetically, O. quilinensis represents an independent lineage only related to a Bolivian tick species of the genus Ornithodoros yet not formally described.
\end{abstract}

\section{Keywords}

Ornithodoros quilinensis, Argasidae, Chacoan region, Argentina

\section{Introduction}

Currently there are 899 species of ticks described around the world, 195 species are included in the family Argasidae (soft ticks), 703 species belong to the family Ixodidae (hard ticks), and the only member of the family Nuttalliellidae is the African species Nuttalliella namaqua Bedford, 1931 (Guglielmone et al. 2010, Nava et al. 2010, Apanaskevich et al. 2011, Dantas-Torres et al. 2012). Specifically for the Neotropical region, the specific richness of ticks is represented by 116 species of hard ticks (Guglielmone et al. 2003, Labruna et al. 2005, Barros-Battesti et al. 2007, Nava et al. 2009) and 83 of soft ticks (Guglielmone et al. 2003, Labruna and Venzal 2009, Nava et al. 2010, Dantas-Torres et al. 2012).

As a result of the increment of the number of studies focused on soft ticks in the last 10 years in South America, several new species of the family Argasidae were described in this continent using both morphological and molecular characters. In this way, the recent description of new species belonging to different genera [Argas keiransi Estrada-Peña, Venzal et González-Acuña, 2003; Antricola guglielmonei
Estrada-Peña, Barros-Battesti et Venzal, 2004; Antricola delacruzi Estrada-Peña, Barros-Battesti et Venzal, 2004; Antricola inexpectata Estrada-Peña, Barros-Battesti et Venzal, 2004; Ornithodoros rondoniensis (Labruna, Terassini, Camargo, Brandão, Ribeiro et Estrada-Peña, 2008); Ornithodoros rioplatensis Venzal, Estrada-Peña et Mangold, 2008; Ornithodoros fonsecai (Labruna et Venzal, 2009); Nothoaspis amazoniensis Nava, Venzal et Labruna, 2010; Ornithodoros cavernicolous Dantas-Torres, Venzal et Labruna, 2012] has put in evidence that the diversity of argasid ticks in the Neotropics is probably underestimated.

To date, only 4 species of the genus Ornithodoros Koch, 1844 have been recorded in Argentina, namely Ornithodoros mimon Kohls, Clifford et Jones, 1969; Ornithodoros rostratus Aragão, 1911; Ornithodoros hasei (Schulze, 1935) and O. rioplatensis (Guglielmone and Nava 2005, Nava et al. 2007, Venzal et al. 2008). Dios and Knopoff (1930) cited Ornithodoros turicata (Dugès, 1876) for Argentina, but Aragão (1935) determined these ticks as $O$. rostratus. In the same way, Boero (1957) and Capriles and Gaud (1977) mentioned the presence of Ornithodoros talaje (Guérin-Méneville, 1849) and Ornithodoros puertoricensis Fox, 1947 in Argentina, respec- 
tively, but Venzal et al. (2008) suggested that these records correspond to $O$. rioplatensis. The aim of this work is to describe a new tick species of Ornithodoros from specimens collected on small rodents in a locality belonging to the Chacoan region of Argentina.

\section{Materials and methods}

Ninety-six larvae of ticks belonging to the genus Ornithodoros were collected on specimens of the small rodent Graomys centralis (Thomas, 1902) (Rodentia: Cricetidae) in Quilino (30

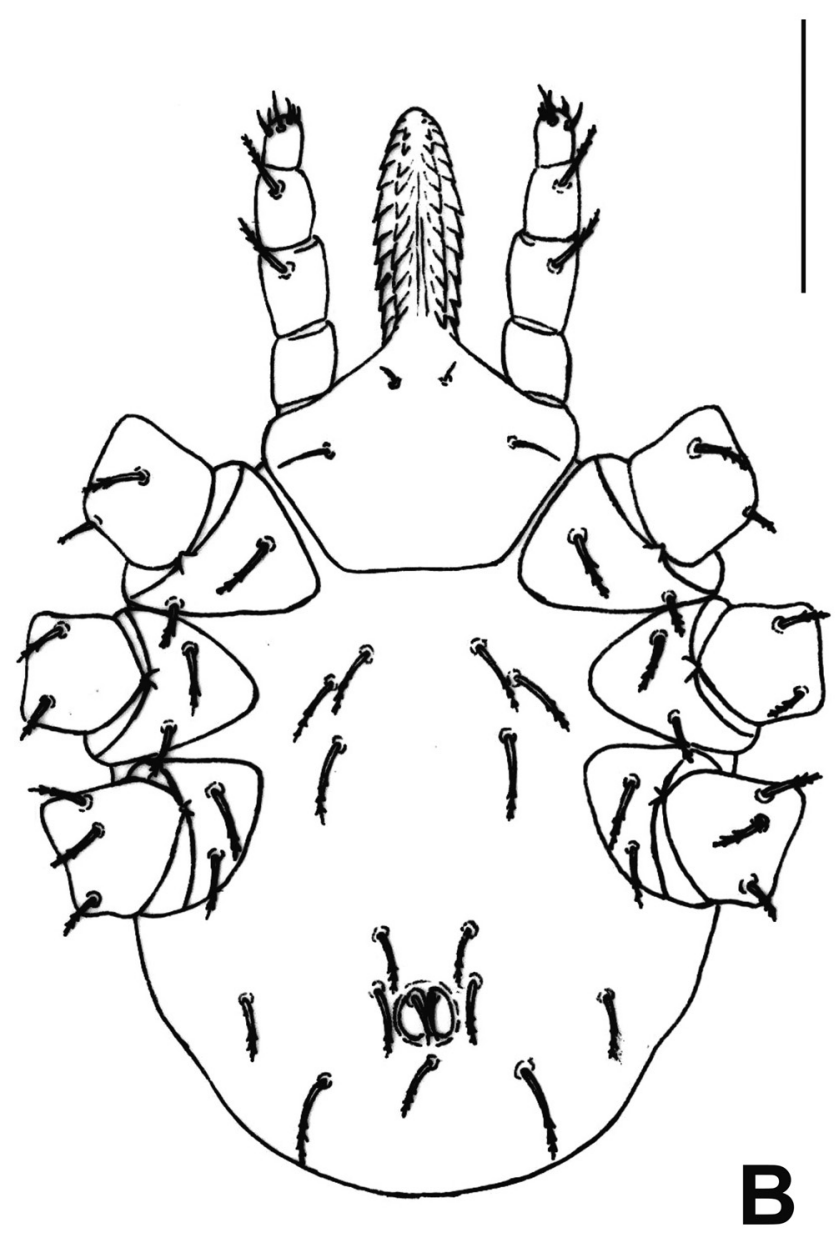

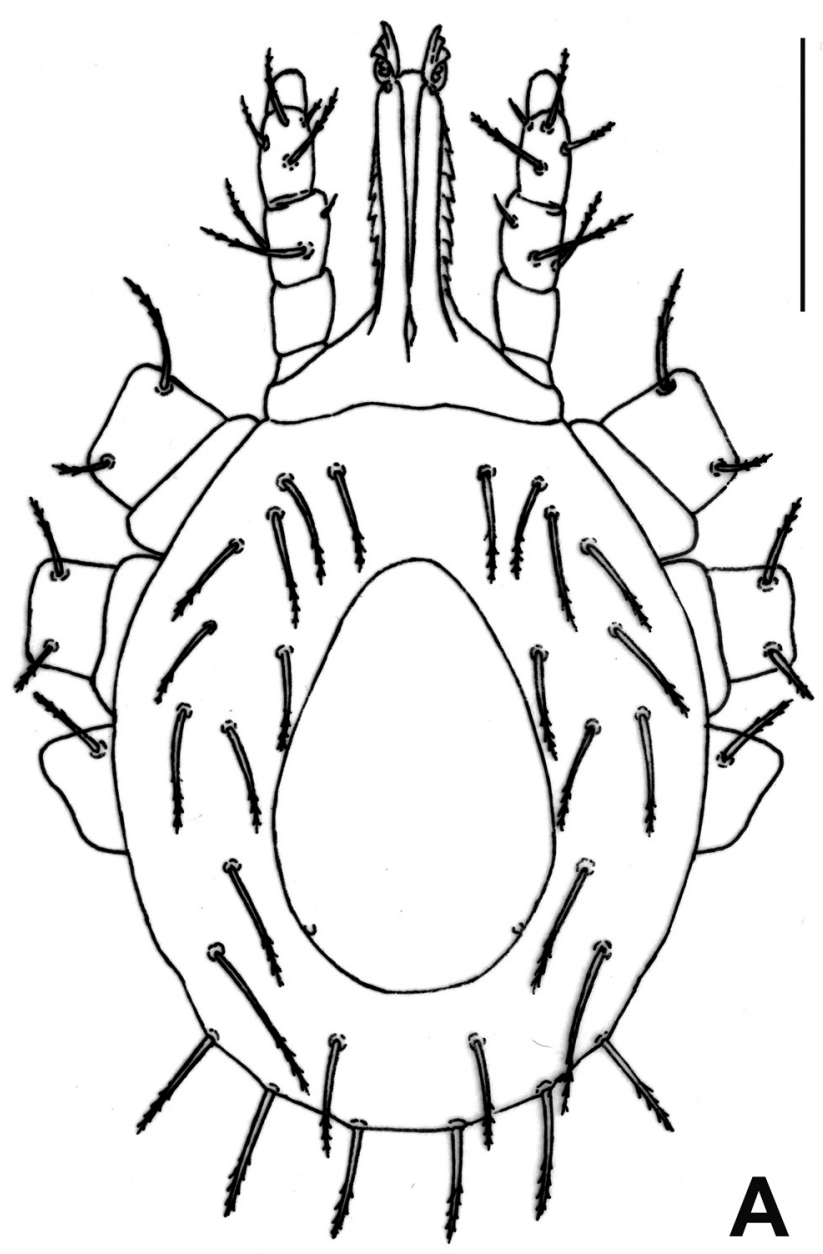

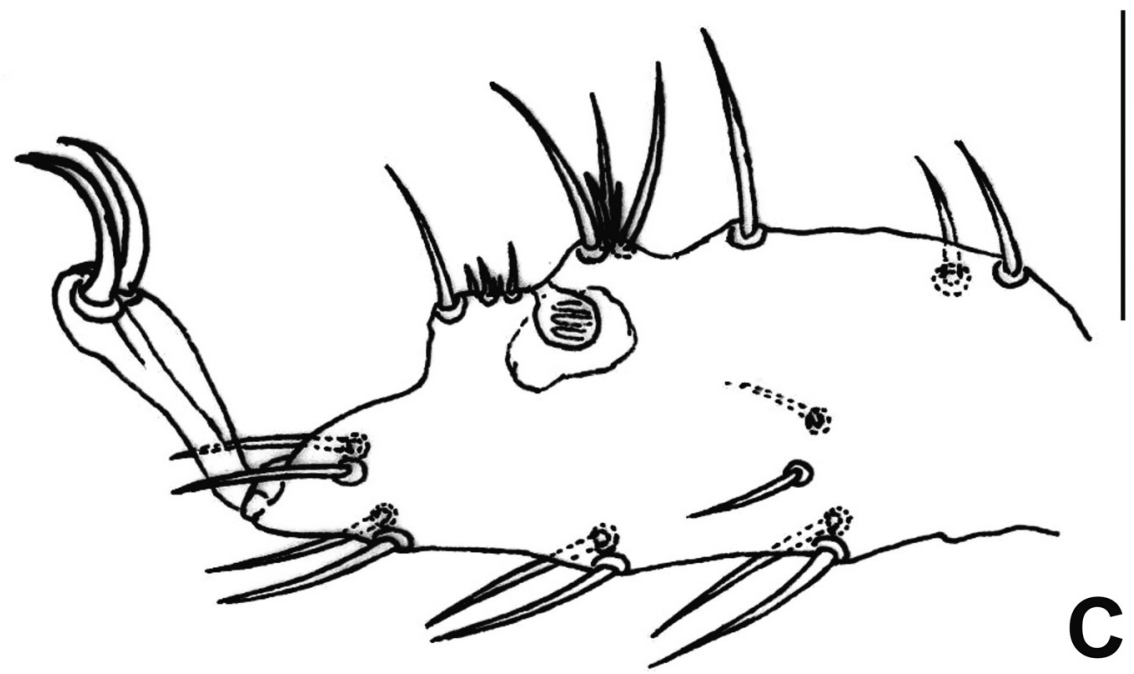

Fig. 1. Ornithodoros quilinensis sp. nov. larva. A - dorsal. B - ventral. C - tarsus I. Scale bars $=150 \mu \mathrm{m}(\mathrm{A}-\mathrm{B}), 50 \mu \mathrm{m}(\mathrm{C})$ 
$\left.12^{\prime} \mathrm{S}, 64^{\circ} 32^{\prime} \mathrm{W}\right)$, Córdoba Province, Argentina, on April 20, 2010. Additionally, 4 larvae morphologically identical were found on G. centralis in the same locality at March 22, 2011. This locality lies in a dry area of the Western Chaqueño District located in the Chaco phytogeographic province according to the phytogeographic divisions described by Cabrera (1994).

Ticks were cleaned with ultrasound $(20 \mathrm{kHz})$ using distilled water and commercial detergent in a proportion of 9:1. Twenty-seven slightly or not engorged larvae were mounted in Hoyer's medium to create semi-permanent slides for light microscopy. Ten larvae were measured using a Nikon Eclipse E200 optical microscope. All measurements are given in micrometres $(\mu \mathrm{m})$, with the mean followed by the standard deviation and range in parentheses. In the descriptions, larval chaetotaxic terminology and measures followed Sonenshine et al. (1962) and Kohls et al. (1965), with the modifications proposed by Venzal et al. (2008) and Labruna et al. (2011).
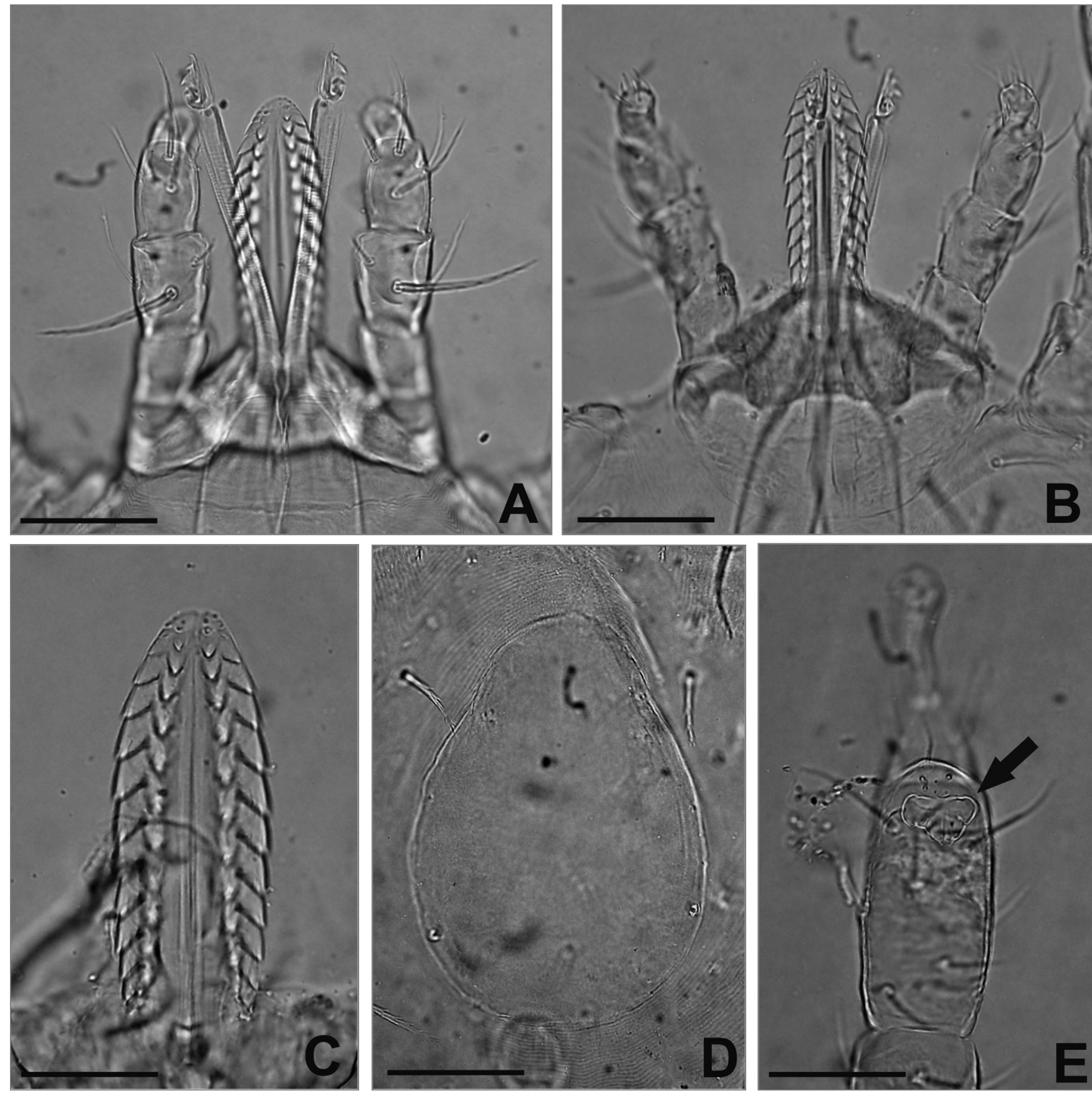

Fig. 2. Ornithodoros quilinensis sp. nov. larva. A - capitulum dorsal. B - capitulum ventral. C - hypostome. D - dorsal plate. E - capsule of Haller's organ (dorsal view). Scale bars $=75 \mu \mathrm{m}(\mathrm{A}-\mathrm{D}), 100 \mu \mathrm{m}(\mathrm{B}), 50 \mu \mathrm{m}(\mathrm{C}-\mathrm{E})$. 
DNA was extracted from 2 larvae (one collected in 2010 and other in 2011) and processed using a polymerase chain reaction (PCR). A 460-bp fragment of the mitochondrial 16S rDNA gene was amplified with the primers designed by Mangold et al. (1998). Each of the sequences was aligned with each other and with the corresponding sequences of the $\mathrm{Or}$ nithodoros species available in GenBank, using the BioEdit Sequence Alignment Editor (Hall 1999) with the CLUSTAL W program (Thompson et al. 1994). Phylogenetic relationships were assessed in terms of neighbour-joining distances (NJ) and maximum parsimony (MP) methods using MEGA version 4.0 (Tamura et al. 2007). The NJ tree was generated from the Tamura-Nei model and gaps were excluded in the pairwise comparison. MP analysis was performed using the heuristic search procedure, with the close neighbour interchange (CNI) set at search level 3 and the random addition of taxa (10 replicates), and gaps were excluded from the analysis. Support for the NJ and MP topology was tested by bootstrapping over 1,000 replications. The sequences of Argas neghmei Kohls et Hoogstraal, 1961 and A. keiransi were used as outgroups.

At the present, there is not consensus among tick researchers about classification of soft ticks at the genus level (Estrada Peña et al. 2010). Therefore, we follow the classification presented by Guglielmone et al. (2010) only to locate the species analyzed in a classificatory scheme, but not in order to support this classification instead of those proposed by other authors (see Estrada Peña et al. 2010).

\section{Results}

Ixodida Leach, 1815

Argasidae Canestrini, 1890

Ornithodoros Koch, 1844

Ornithodoros quilinensis Venzal, Nava et Mangold (Figs 1-2)

\section{Larva}

Body: Idiosoma oval; length with capitulum $525 \pm 25$ (503579), length without capitulum $358 \pm 28$ (332-427), width 325 $\pm 42(247-380)$.

Dorsum: Dorsal plate oval, length $200 \pm 17$ (172-221), width $152 \pm 7$ (141-168). Dorsal surface provided with 14 pairs of setae, 7 anterolateral, 3 central and 4 posterolateral. Anterolateral setae (Al): $\mathrm{Al}_{1}$ length $60 \pm 3$ (55-65), $\mathrm{Al}_{2}$ length $62 \pm 2$ (60-67), $\mathrm{Al}_{3}$ length $60 \pm 5$ (53-67), $\mathrm{Al}_{4}$ length $61 \pm 5$ (53-67), $\mathrm{Al}_{5}$ length $64 \pm 5$ (57-72), $\mathrm{Al}_{6}$ length $66 \pm 4$ (57-74), $\mathrm{Al}_{7}$ length $70 \pm 3$ (67-74). Central setae (C): $\mathrm{C}_{1}$ length $51 \pm 3$ (48-55), $\mathrm{C}_{2}$ length $73 \pm 4$ (67-79), $\mathrm{C}_{3}$ length $71 \pm 4$ (62-77). Posterolateral setae (Pl): $\mathrm{Pl}_{1}$ length $79 \pm 4$ (72-84), $\mathrm{Pl}_{2}$ length $79 \pm 6$ (69-89), $\mathrm{Pl}_{3}$ length $77 \pm 4$ (67-84), $\mathrm{Pl}_{4}$ length $77 \pm 5$ (67-84).

Venter: Ventral surface provided with 7 pairs of setae plus 1 pair on anal valves, 1 posteromedian seta present. Three pairs of sternal setae (St): $\mathrm{St}_{1}$ length $46 \pm 2$ (41-50), $\mathrm{St}_{2}$ length $45 \pm 2$ (41-48), $\mathrm{St}_{3}$ length $44 \pm 3$ (38-50); one pair of postcoxal setae (Pc) length $38 \pm 4$ (31-43); three pairs of circumanal setae (Ca): $\mathrm{Ca}_{1}$ length $40 \pm 2$ (36-43), $\mathrm{Ca}_{2}$ length $40 \pm 3$ (36-45), $\mathrm{Ca}_{3}$ length $50 \pm 5$ (38-57); posteromedian setae (PM) length $42 \pm 5$ (36-50).

Capitulum: Basis capituli pentagonal, posterior margin straight, length from posterior margin of basis capituli to posthypostomal setae: $\mathrm{Ph}_{1} 91 \pm 3$ (86-96), length from posterior margin of basis capituli to insertion of hypostome $104 \pm$ 4 (98-113), length from posterior margin of basis capituli to apex of hypostome $222 \pm 6$ (209-230), width $151 \pm 5$ (144156). Two pairs of posthypostomal setae; $\mathrm{Ph}_{1}$ length $14 \pm 2$ (12-17), $\mathrm{Ph}_{2}$ length $31 \pm 2$ (29-36), distance between $\mathrm{Ph}_{1}$ setae $16 \pm 2$ (14-19), distance between $\mathrm{Ph}_{2}$ setae $74 \pm 5$ (65-86). Palpi total length $143 \pm 6$ (132-151), segmental length/width from I-IV: (I) $37 \pm 1$ (36-41)/34 \pm 2 (31-38), (II) $43 \pm 3$ (38$48) / 35 \pm 1$ (33-38), (III) $43 \pm 2(43-48) / 31 \pm 1$ (29-33), (IV) $24 \pm 3(19-29) / 20 \pm 1$ (19-21). Setae number on palpal articles I-IV: (I) 0, (II) 4, (III) 5, (IV) 9.

Hypostome: length from $\mathrm{Ph}_{1}$ to apex $133 \pm 7$ (120-141), length from insertion of hypostome in basis capituli to apex $118 \pm 4$ (110-122), width in medial basis portion of hypostome $43 \pm 2$ (41-48), width in basis portion of hypostome 36 \pm 3 (33-41); hypostome narrower at the base, and apex blunt. Dentition formula $2 / 2$ throughout entire length, file 1 with 13 to 15 denticles, file 2 with 11 to 14 denticles, some specimens with 1 accessory file with 1 denticle; corona in apex with 2 very small denticles.

Legs: Tarsus I length $129 \pm 2$ (127-134), tarsus I width 53 \pm 2 (48-57). Setal formula of tarsus I: 1 pair apical (A), 1 distomedian (DM), 5 paracapsular (PC), 1 posteromedian (PM), 1 pair basal (B), 1 pair apicoventral (AV), 1 pair midventral (MV), 1 pair basiventral (BV), and 1 pair posterolateral (PL). Capsule of Haller's organ: irregular in shape, without reticulations.

\section{Taxonomic summary}

Type host: Graomys centralis (Thomas, 1902).

Type locality: Quilino $\left(30^{\circ} 12^{\prime} \mathrm{S}, 64^{\circ} 32^{\prime} \mathrm{W}\right)$, Córdoba Province, Argentina.

Type specimens: Holotype larva, allotype larva, 3 paratype larvae mounted in same slide, 5 paratype larvae mounted in other slide and 10 paratype larvae in $70 \%$ ethanol, collected on April 20, 2010 by A.J. Mangold, S. Nava, J.M. Venzal and M. Mastropaolo on G. centralis, deposited in the U.S National Tick Collection, Georgia Southern University, Statesboro (RML 124999); 5 paratype larvae mounted in slide and 5 in $70 \%$ ethanol, same data as for holotype, deposited in the tick collection of INTA Rafaela, Santa Fe, Argentina (INTA 2179); 8 paratype larvae mounted in three slides and 5 in $70 \%$ ethanol, same data as for holotype, deposited in the tick collection of the Departamento de Parasitología Veterinaria, Facultad de Veterinaria, Universidad de la República, Monte- 
Table I. Comparison of larval morphological characters between O. quilinensis sp. nov. and other similar Neotropical Ornithodoros species (1)

\begin{tabular}{|c|c|c|c|c|c|c|c|}
\hline & $\begin{array}{c}\text { Ornithodoros } \\
\text { quilinensis }\end{array}$ & $\begin{array}{l}\text { Ornithodoros } \\
\text { mimon }\end{array}$ & $\begin{array}{c}\text { Ornithodoros } \\
\text { echimys }\end{array}$ & $\begin{array}{c}\text { Ornithodoros } \\
\text { casebeeri }\end{array}$ & $\begin{array}{c}\text { Ornithodoros } \\
\text { chironectes }\end{array}$ & $\begin{array}{c}\text { Ornithodoros } \\
\text { tuttlei }\end{array}$ & $\begin{array}{l}\text { Ornithodoros } \\
\text { talaje group }\end{array}$ \\
\hline Dorsal plate & oval & pyriform & pyriform & pyriform & pyriform & pyriform & pyriform \\
\hline Dorsal setae: total pairs & 14 & $13-15$ & 14 & $17-18$ & $16-17$ & 15 & $17-20$ \\
\hline Hypostome: length & $120-141$ & $200-220$ & $204-220$ & $232-235$ & 179-200 & $255-291$ & $200-280$ \\
\hline Apex of hypostome & blunt & blunt & rounded & rounded & rounded & rounded & pointed \\
\hline References & This study & $\begin{array}{l}\text { Kohls et al. } \\
1969, \\
\text { Barros-Battesti } \\
\text { et al. } 2011\end{array}$ & $\begin{array}{c}\text { Kohls et al. } \\
1969\end{array}$ & $\begin{array}{c}\text { Jones and } \\
\text { Clifford, } 1972\end{array}$ & $\begin{array}{c}\text { Jones and } \\
\text { Clifford, } 1972\end{array}$ & $\begin{array}{c}\text { Jones and } \\
\text { Clifford, } 1972\end{array}$ & $\begin{array}{c}\text { Venzal et al. } \\
2008\end{array}$ \\
\hline
\end{tabular}

(1) Measurements are in $\mu \mathrm{m}$.

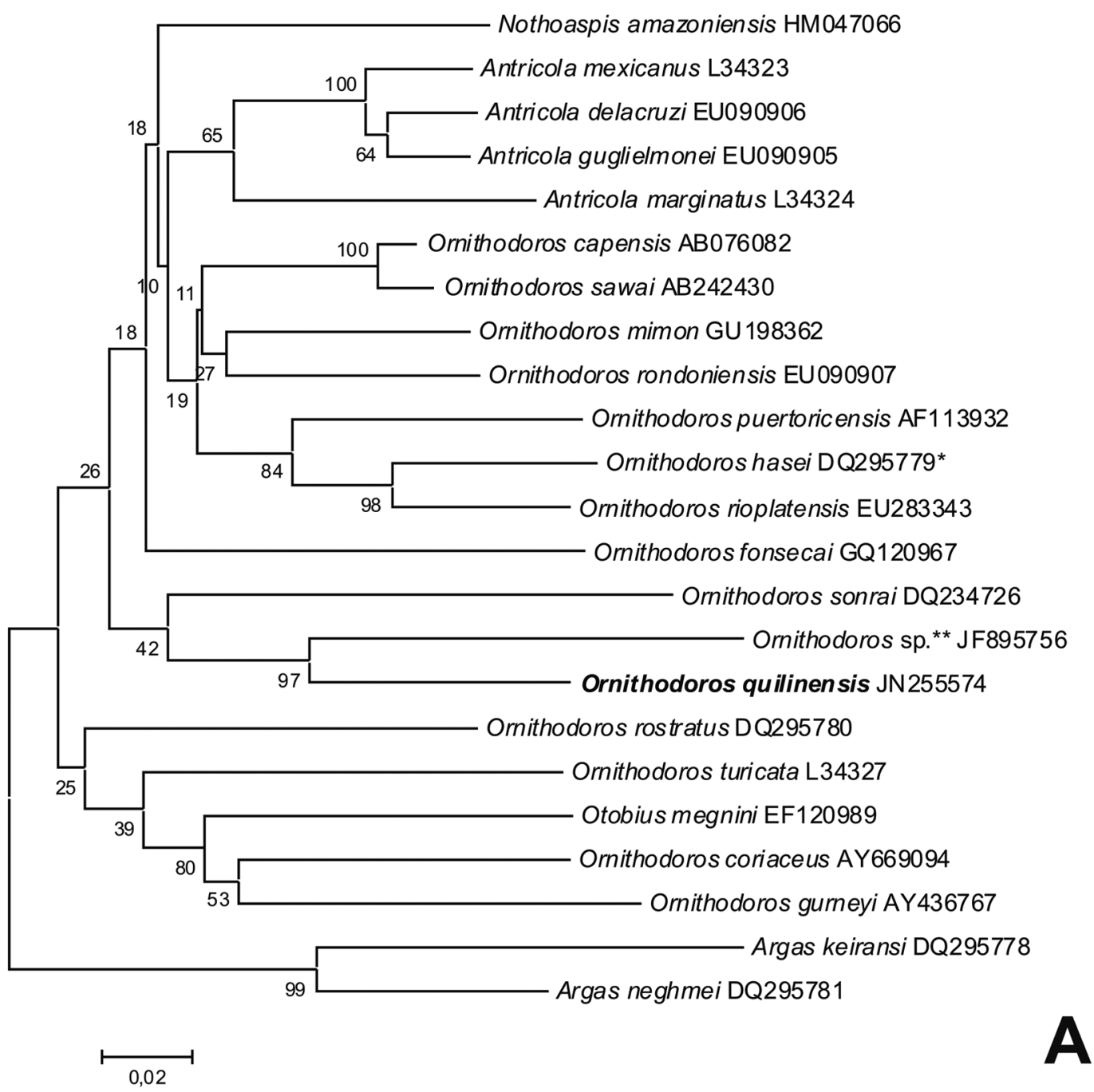




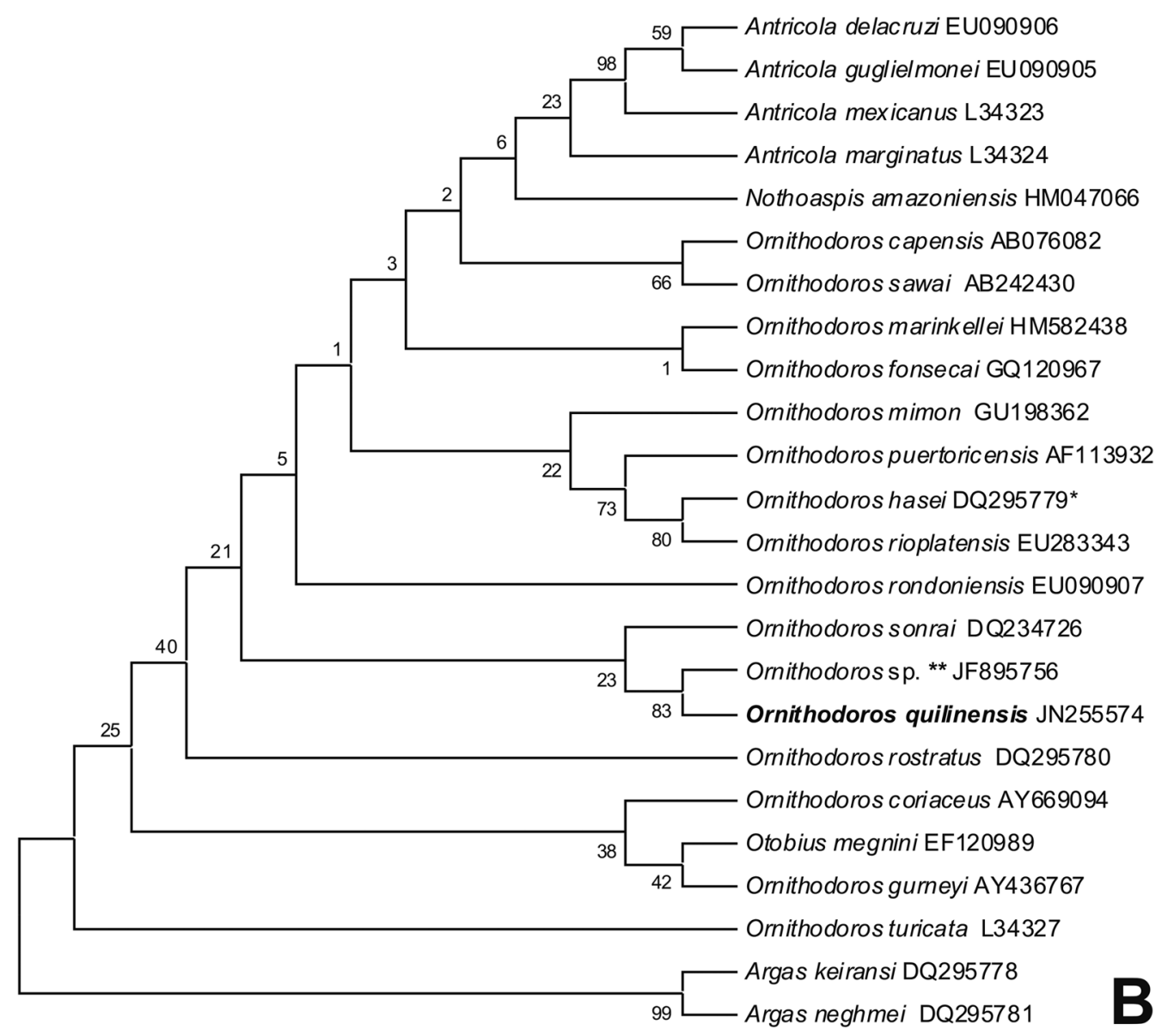

Fig. 3. Neighbour-joining (A) and maximum parsimony (B) trees based on 16S rDNA partial sequences. Numbers represent bootstrap support generated from 1,000 replications. Numbers in brackets are GenBank accession numbers. *The specimen used to obtain this sequence was erroneously classified as Ornithodoros mimon when the sequence was submitted to GenBank (J.M. Venzal, pers. comm.). ** Sequence obtained from a tick specimen collected in Bolivia and determined by Parola et al. (2011) as Ornithodoros sp. According to these authors, this Bolivian tick is probably a new species.

video, Uruguay (DPVURU 769, 770, 771); 2 paratype larvae mounted in slide and 5 in $70 \%$ ethanol, same data as for holotype, deposited in the tick collection in the Faculdade de Medicina Veterinária e Zootecnia, Universidade de São Paulo, São Paulo, Brazil (CNC-1917); 2 paratype larvae mounted in slide and 5 in $70 \%$ ethanol, same data as for holotype, deposited in the Instituto Butantan, São Paulo, Brazil (IBSP-10.720). Etymology: The specific epithet "quilinensis" refers to the locality (Quilino) where the type specimens were collected.

\section{Species relationship}

The diagnostic characters unique for the larva of $O$. quilinensis are its small size $(520-540 \mu \mathrm{m})$, a dorsal plate oval in shape with a length of approximately $200 \mu \mathrm{m}, 14$ pairs of dorsal setae, hypostome short and narrower at the base (length from $\mathrm{Ph}_{1}$ to apex $\left.133 \pm 7(120-141)\right)$ with dental formula $2 / 2$ and apex blunt, and the capsule of the Haller's organ irregular in shape and without reticulations. The combination of these morphological characters allows differentiating the larva of $O$. quilinensis from the remaining larvae of the genus $\mathrm{Or}$ nithodoros that were described in the western hemisphere.

A comparison of larval morphological characters of O. quilinensis with other similar Neotropical Ornithodoros species is shown in Table I.

The larva of $O$. quilinensis share with $O$. mimon the small size of unengorged specimens, the number of dorsal setae (14 pairs) and the hypostome with apex blunt. However, both species can be easily separated because in $O$. mimon the dental formula in the apex of the hypostome is $4 / 4(2 / 2$ in O. quilinensis), and the dorsal plate is pyriform in shape (oval in O. quilinensis).

Ornithodoros quilinensis is also morphologically related to a group of Neotropical Ornithodoros species which are associated to small rodents and marsupials. They share a hypostome with apex blunt, the dorsal plate oval in shape, and the number of dorsal setae. Larvae of Ornithodoros echimys Kohls, Clifford et Jones, 1969 and O. quilinensis have a dor- 
sal plate similar in shape and size, and 14 pairs of dorsal setae, but $O$. echimys has a longer hypostome $(200-220 \mu \mathrm{m})$ without denticles in its base, and a dental formula $4 / 4$ in anterior portion of hypostome. Most of the records of O. echimys correspond to larvae collected on Echimys semivillosus (I. Geoffroy, 1838) (Rodentia: Echimyidae) in Venezuela, with the only exception of a record on Marmosa sp. (Didelphimorphia: Didelphidae) in Bolivia (Kohls et al. 1969; Jones et al. 1972). Other species morphologically related to O. quilinensis is $\mathrm{Or}$ nithodoros casebeeri Jones et Clifford, 1972, but they are easily distinguished because $O$. casebeeri has a dental formula $3 / 3$ and anterior projections on the base of hypostome. Larvae of this tick were found on Ototylomys sp. (Rodentia: Cricetidae) in Costa Rica and on Peromyscus stirtoni Dickey, 1928 (Rodentia: Cricetidae) in Nicaragua (Jones and Clifford 1972). Ornithodoros chironectes Jones et Clifford, 1972 is also similar to $O$. quilinensis, but $O$. chironectes has 16-17 pairs of dorsal setae, a dorsal plate pyriform in shape, and dental formula is $3 / 3$ in anterior portion of hypostome. All records of larvae of $O$. chironectes were made on Chironectes minimus (Zimmermann, 1780) (Didelphimorphia: Didelphidae) and Sigmodon hispidus Say et Ord, 1825 (Rodentia: Cricetidae) in Nicaragua (Jones and Clifford 1972). The other species of this group, Ornithodoros tuttlei Jones et Clifford, 1972, is differentiate from $O$. quilinensis by the dental formula $5 / 5$ (O. quilinensis has 2/2). The findings of $O$. tuttlei correspond to larvae collected on Cuniculus paca (Linnaeus, 1766) (Rodentia: $\mathrm{Cu}-$ nicuidae) and Tapirus terrestris (Linnaeus, 1758) (Perissodactyla: Tapiridae) in Venezuela (Jones and Clifford 1972).

Finally, O. quilinensis should be compared with the species belonging to the Ornithodoros talaje species group, which is formed by Ornithodoros talaje (Guérin- Méneville, 1849), Ornithodoros puertoricensis Fox, 1947 and O. rioplatensis (Venzal et al. 2008). Larvae of these 3 species can be distinguished from $O$. quilinensis larvae by the presence of a dorsal plate pyriform, hypostome pointed and dorsal setae more numerous (17-20 pairs in $O$. talaje species group and 14 pairs in $O$. quilinensis).

\section{Molecular analysis}

The two sequences of the larvae determined as $O$. quilinensis (GenBank accession numbers JN255574 and JN255575) only differed in one (position 256) of the 449 nucleotides.

The topologies of NJ and MP trees are showed in Figure 3. In both phylogenetic reconstructions, $O$. quilinensis only was closely related with a tick from Bolivia determined by Parola et al. (2011) as Ornithodoros sp. According to these authors, this Bolivian tick is probably a new species. Unfortunately, there are not available sequences of $O$. echimys, O. casebeeri and $O$. chironectes, which share with $O$. quilinensis a similar morphology and the same type of host (small terrestrial mammals). From a phylogenetic perspective, O. quilinensis appear to be an independent lineage, only related to a tick species not formally described. However, these results on the phyloge- netic position of $O$. quilinensis should be considered carefully because the aforementioned lack of available sequences of argasid species and the use of only one gene.

Acknowledgements. We acknowledge the financial support of INTA, Asociación Cooperadora EEA-INTA Rafaela and CONICET to $\mathrm{SN}, \mathrm{AJM}, \mathrm{MM}$ and AAG.

\section{References}

Apanaskevich D.A., Horak I.G., Matthee C., Matthee S. 2011. A new species of Ixodes (Acari: Ixodidae) from South African mammals. Journal of Parasitology, 97, 389-398. DOI: 10.1645/ GE-2366.1.

Aragão H. 1935. Observações sobre os ixodideos da Republica Argentina. Memórias do Instituto Oswaldo Cruz, 30, 519-533.

Barros-Battesti D.M., Arzua M., Onofrio V.C., Labruna M.B. 2007. Validation and redescription of Amblyomma romitii TonelliRondelli, 1939 (Acari: Ixodidae). Systematic Parasitology, 68, 79-86. DOI: 10.1007/s11230-006-9079-x.

Barros-Battesti D.M., Landulfo G.A., Onofrio V.C., Faccini J.L.H., Marcili A., Nieri-Bastos F.A., Venzal J.M., Labruna M.B. 2011. Carios mimon (Acari: Argasidae): description of adults and redescription of larva. Experimental and Applied Acarology, 54, 93-104. DOI: 10.1007/s10493-010-9416-2.

Boero J.J. 1957. Las garrapatas de la República Argentina (Acarina: Ixodoidea). Departamento Editorial de la Universidad de Buenos Aires, Buenos Aires, 113 pp.

Cabrera A.L. 1994. Regiones fitogeográficas argentinas. Acme, Buenos Aires, Argentina, 85 pp.

Capriles J.M., Gaud S.M. 1977. The ticks of Puerto Rico (Arachnida: Acarina). Journal of Agriculture of the University of Puerto Rico, 61, 402-404.

Dantas-Torres F., Venzal J.M., Bernardi L.F.O., Ferreira R.L., Onofrio V.C., Marcili A., Bermúdez S.E., Ribeiro A.F., Barros-Battesti D.M., Labruna M.B. 2012. Description of a new species of bat-associated argasid tick (Acari: Argasidae) from Brazil. Journal of Parasitology, 98, 36-45. DOI: 10.1645/GE2840.1.

Dios R., Knopoff R. 1930. Sobre Ixodoidea de la República Argentina. Revista de la Sociedad Argentina de Biología, 6, 593627.

Estrada-Peña A., Mangold A.J., Nava S., Venzal J.M., Labruna M.B., Guglielmone A.A. 2010. A review of the systematics of the family Argasidae (Ixodida). Acarologia, 50, 317-333. DOI: 10.1051/acarologia/20101975.

Guglielmone A.A., Estrada Peña A., Keirans J.E., Robbins R.G. 2003. Ticks (Acari: Ixodida) of the Neotropical Zoogeographic Region. ICTTD-2, Atalanta, Houten, The Netherlands, $174 \mathrm{pp}$.

Guglielmone A.A., Nava S. 2005. Las garrapatas de la familia Argasidae y de los géneros Dermacentor, Haemaphysalis, Ixodes y Rhipicephalus (Ixodidae) de la Argentina: distribución y hospedadores. Revista de Investigaciones Agropecuarias, 34, 123-141.

Guglielmone A.A., Robbins R.G., Apanaskevich D.A., Petney T.A., Estrada-Peña A., Horak I.G., Shao R., Barker S.C. 2010. The Argasidae, Ixodidae and Nuttalliellidae (Acari: Ixodida) of the world: a list of valid names. Zootaxa, 2528, 1-28.

Hall T.A. 1999. BioEdit: a user friendly biological sequence alignment editor and analysis program for Windows 95/98/NT. Nucleic Acids Symposium Series, 41, 95-98.

Jones E.K., Clifford C.M. 1972. The systematics of the subfamily Ornithodorinae (Acarina: Argasidae). V. A revised key to lar- 
val Argasidae of the Western Hemisphere and description of seven new species of Ornithodoros. Annals of the Entomological Society of America, 65, 730-740.

Jones E.K., Clifford C.M., Keirans J.E., Kohls G.M. 1972. The ticks of Venezuela (Acarina: Ixodoidea) with a key to the species of Amblyomma in the Western Hemisphere. Brigham Young University Science Bulletin, Biological Series, 17, 1-40.

Kohls G.M., Clifford C.M., Jones E.K. 1969. The systematics of the subfamily Ornithodonnae (Acarina: Argasidae). IV. Eight new species of Ornithodoros from the Western Hemisphere. Annals of the Entomological Society of America, 62, 1035-1043.

Kohls G.M., Sonenshine D.E., Clifford C.M. 1965. The systematics of the subfamily Ornithodorinae (Acarina: Argasidae). II. Identification of the larvae of the western hemisphere and descriptions of three new species. Annals of the Entomological Society of America, 58, 331-364.

Labruna M.B., Keirans J.E., Camargo L.M.A., Ribeiro A.F., Soares R.M., Camargo E.P. 2005. Amblyomma latepunctatum, a valid tick species (Acari: Ixodidae) long misidentified with both Amblyomma incisum and Amblyomma scalpturatum. Journal of Parasitology, 91, 527-541. DOI: 10.1645/GE-446R.

Labruna M., Nava S., Terassini F., Onofrio V., Barros-Battesti D., Camargo L.M., Venzal J.M. 2011. Description of adults, nymph and redescription of the larva of Ornithodoros marinkellei (Acari: Argasidae), with data on its phylogenetic position. Journal of Parasitology, 97, 207-217. DOI: 10.1645/ GE-2620.1.

Labruna M.B., Venzal J.M. 2009. Carios fonsecai sp. nov. (Acari, Argasidae), a bat tick from the central-western region of Brazil. Acta Parasitologica, 54, 355-363. DOI: 10.2478/ s11686-009-0051-1.

Mangold A.J., Bargues M.D., Mas-Coma S. 1998. Mitochondrial 16S rRNA sequences and phylogenetic relationships of Rhipicephalus and other tick genera among Metastriata (Acari: Ixodidae). Parasitology Research, 84, 478-484. DOI: 10.1007/ s004360050433.

Nava S., Mangold A.J., Mastropaolo M., Venzal J.M., Oscherov E.B., Guglielmone A.A. 2009. Amblyomma boeroi n.sp. (Acari:
Ixodidae), a parasite of the Chacoan peccary Catagonus wagneri (Rusconi) (Artiodactyla: Tayassuidae) in Argentina. Systematic Parasitology, 73, 161-174. DOI: 10.1007/s11230009-9191-9.

Nava S., Venzal J.M., Díaz M.M., Mangold A.J., Guglielmone A.A. 2007. The Ornithodoros hasei (Schulze, 1935) species group in Argentina. Systematic and Applied Acarology, 12, 27-30.

Nava S., Venzal J.M., Terassini F.A., Mangold A.J., Camargo L.M.A., Labruna M.B. 2010. Description of a new argasid tick (Acari: Ixodida) from bat caves Brazilian Amazon. Journal of Parasitology, 96, 1089-1101. DOI: 10.1645/GE-2539.1.

Parola P., Ryelandt J., Mangold A.J., Mediannikov O., Guglielmone A.A., Raoult D. 2011. Relapsing fever Borrelia in Ornithodoros ticks from Bolivia. Annals of Tropical Medicine and Parasitology, 105, 407-411. DOI: 10.1179/136485941 1Y.0000000021.

Sonenshine D.E., Clifford C.M., Kohls G.M. 1962. The identification of larvae of the genus Argas (Acarina: Argasidae). Acarologia, 4, 193-214.

Tamura K., Dudley J., Nei M., Kumar S. 2007. MEGA 4: Molecular evolutionary genetics analysis (MEGA) software version 4.0. Molecular Biology and Evolution, 24, 1596-1599. DOI: 10.1093/molbev/msm092.

Thompson J.D., Higgins D., Gibson T.J. 1994. CLUSTAL W: improving the sensitivity of progressive multiple sequence alignment through sequence weighting, position-specific gap penalties and weight matrix choice. Nucleic Acids Research, 22, 4673-4680. DOI: 10.1093/nar/22.22.4673.

Venzal J.M., Estrada-Peña A., Mangold A.J., González-Acuña D., Guglielmone A.A. 2008. The Ornithodoros (Alectorobius) talaje species group (Acari: Ixodida: Argasidae): description of Ornithodoros (Alectorobius) rioplatensis n.sp. from southern South America. Journal of Medical Entomology, 45, 832-840. DOI: http://dx.doi.org/10.1603/0022-2585(2008)45[832:TO ATSG]2.0.CO;2.

(Accepted April 12, 2012) 